\title{
Spontaneous Hybridization of Coffee Varieties and Species in Puerto Rico ${ }^{1}$
}

\section{T. Singh-Dhaliwal, P. Meléndez-Gonzîles, and A. Torres Sepulveda ${ }^{2}$ \\ INTRODUCTION}

Puerto Rican, Columnaris, and Bourbon varieties of Coffea arabica $\mathrm{L}$. are commonly grown in Puerto Rico. In some localities there are small plantings also of other coffees, such as Excelsa (C. excelsa Chev.) and Robusta ( $C$. canephora Pierre). Recently some farmers have started testing several newly introduced Arabica-type coffees, such as Caturra, Villalobos, Mundo Novo, Mibirizi, and so on. The farmers generally establish mixed plantings of different coffee varieties and species rather than planting them in separate plots.

The time of flowering of Arabica-type coffees extends from December to June. Excelsa blooms heavily here during June to December, but it continues producing some flowers also during other months of the year. Robusta blooms irregularly almost throughout the year. Quite often all of these coffee species were observed blooming at the same time.

The occurrence of different varieties and species of Co/fea together, and the overlapping of their times of flowering created the possibility of their spontaneous hybridization. Spontaneous hybridization can increase genetic variability for characters such as yield, quality of bean, time of ripening of fruits, and so on, within the coffees involved, and thereby reduce their desirability for commercial production. However, genetic variability can be used for developing new superior coffee varieties. Thus information on spontaneous hybridization is important for seed production and also for the breeding program.

Spontaneous hybridization of coffee varieties and species has been studied in Puerto Rico for many years. The results of such a study are briefly presented in this paper.

1 This investigation was carried on under the Federal-Grant Research Project Hatch 74, Coffee Breeding in Puerto Rico.

2 Plant Breeder and Research Assistants, respectively, Agricultural Experiment Station, University of Puerto Rico, Río Piedras, P.R. The authors are grateful to Jesús Vélez Fortuño, Head, Plant Breeding Department of this Station, for reading the manuscript and making useful suggestions. They also thank the personnel of Adjuntas Substation (Castañer Substation) of this Station for their cooperation during the course of this study. 


\section{REVIEW OF THE LITERATURE}

General observations of many coffee plantings in Puerto Rico indicated that different coffee varieties and species were spontaneously hybridizing $(4)^{3}$.

As reviewed by Krug and Carvalho (2), Cramer (1), and Sybenga (6), several research workers in different coffee-growing regions of the world studied the reproduction methods of species of Coffea. Their work seemed to lead to the conclusion that $C$. arabica is generally self-fertile and predominantly autogamous. The extent of cross-pollination is usually slight. The other species of Coffea, such as C. excelsa, C. canephora, and so on, are self-sterile and predominantly cross-pollinated. Wind, insects, and gravity are responsible for pollen transmission.

Cramer (1) reported the occurrence of spontaneous hybrids of Coffea canephora $\times$ C. arabica and C. canephora $\times$ C. liberica in Indonesia. He also reported that, in clone collections, it was difficult to prevent the mixing of various coffee species that were spontaneously hybridizing. Some of the spontaneous coffee hybrids he found proved to be of economic importance.

Krug and Carvalho (S) reported that Mundo Novo probably originated through natural crossing between a high-yielding strain of Typica (Sumatra strain) and Bourbon.

\section{MATERIALS AND METHODS}

Open-pollinated seed lots were collected from 18 trees of Bourbon growing mixed with Puerto Rican and Columnaris at different locations at the Castañer Substation, and the progenies from them were observed when 9 to 14 months old.

Bourbon, being genetically $b r b r$, has young leaves of light-green color. Puerto Rican and Columnaris, being genetically $\mathrm{Br} B r$, have young leaves bronze in color. The $F_{1}$ hybrids of Bourbon with Puerto Rican and Columnaris being genetically $\mathrm{Br} b r$ have young leaves of a light-bronze color (2). Therefore, in the progenies from open-pollinated seed from Bourbon all the plants with light-bronze young leaves were regarded as spontaneous hybrids of Bourbon with Puerto Rican and Columnaris.

Open-pollinated seed lots were collected from eight trees of Cera (Coffea arabica L.) which grew surrounded by many other Arabica type coffees, in the germ-plasm collection at Castañer Substation. These were classified as to color of endosperm.

Cera, being genetically $c e c e$, produces seed with a yellow endosperm; ce ce ce, and other varieties of Coffea arabica, being genetically $\mathrm{Ce} C e$ produce seed with a greenish endosperm, $\mathrm{Ce} \mathrm{Ce} \mathrm{Ce}$. One allele, $\mathrm{Ce}$ is dominant over two doses of $c e$ in the endosperm (2). Therefore all the open-pollinated

Italio numbers in parentheses refer to Literature Cited p. 279. 
Cera seed with a greenish endosperm were regarded as resulting from natural cross-pollination of Cera with pollen from other Arabica-type coffees.

Seedlings were raised using open-pollinated seed collected from Excelsa, growing mixed with Puerto Rican. They were observed as to the occurrence of spontaneous hybrids when 18 months old. The progenies of the spontaneous hybrids were raised and observed for segregation. Seedlings were raised using open-pollinated seed collected from Robusta, growing mixed with Puerto Rican, and were carefully observed when about 18 months old. As the leaves of Robusta resemble those of Puerto Rican, it was difficult to identify the spontaneous hybrids at this age. However, they could be identified easily, when several years old.

Many experimental and commercial coffee plantings, and nurseries located in different parts of the Coffee Region, were visited and observed to detect the occurrence of spontaneous hybrids.

A large number of intervarietal and interspecific coffee hybrids was synthesized by controlled pollinations and compared with the corresponding spontaneous hybrids found.

\section{RESULTS AND DISCUSSION}

\section{SPONTANEOUS HYBRIDIZATION OF BOURBON WITH}

PUERTO RICAN AND COLUMNARIS

The proportion of spontaneous hybrids in progenies from open-pollinated seed collected from Bourbon, growing mixed with Puerto Rican and Columnaris, varied greatly.

No spontaneous hybrid was found in two small progenies each comprising six plants. In the other 16 progenies the proportion of spontaneous hybrids varied from 1.25 to 34.14 percent. The joint estimate of the proportion of spontaneous hybrids from a total of 4,994 plants comprising all the 18 progenies, was 0.0566 , with a standard error 0.0033 (table 1 ).

Seed were collected from four of the open-pollinated Bourbon trees during 2 consecutive years, and the progenies were raised. The proportion of spontaneous hybrids in the progenies was different during the 2 years, but the differences were not statistically significant (tables 2 and 3 ).

Seed were collected from four of the open-pollinated Bourbon trees at two different dates during the same year, and the progenies were raised. The proportion of spontaneous hybrids in the progenies varied with the date the seed were collected, but the differences were not statistically significant (tables 4 and 5).

Two populations were raised from random samples of open-pollinated seed collected from a Bourbon planting surrounded by Puerto Rican and Columnaris plantings. In one of the populations, out of a total of 672 plants 7.88 percent were spontaneous hybrids. In the other population, 
TABLE 1.-Spontaneous hybrids of Bourbon with Puerto Rican and Columnaris coffees in progenies from seed picked during 2 crops, 1959-60, at the

Agricultural Experiment Substation, Castañer, P.R.

\begin{tabular}{|c|c|c|c|}
\hline Progeny ${ }^{1}$ No. & Seedlings & Hybrids & Proportion of hybrids 2 \\
\hline & Number & Number & Percent \\
\hline 1 & 424 & 15 & 3.53 \\
\hline 2 & 786 & 88 & 11.19 \\
\hline 3 & 642 & 15 & 2.33 \\
\hline 4 & 724 & 17 & 2.34 \\
\hline 5 & 378 & 8 & 2.11 \\
\hline 6 & 399 & 30 & 7.51 \\
\hline 7 & 406 & 10 & 2.46 \\
\hline 8 & 399 & 5 & 1.25 \\
\hline 9 & 413 & 9 & 2.17 \\
\hline 10 & 123 & 42 & 34.14 \\
\hline 11 & 27 & 3 & 11.11 \\
\hline 12 & 24 & 3 & 12.50 \\
\hline 13 & 6 & 0 & - \\
\hline 14 & 6 & 0 & - \\
\hline 15 & 28 & 8 & 28.57 \\
\hline 16 & 160 & 26 & 16.25 \\
\hline 17 & 28 & 2 & 7.14 \\
\hline 18 & 21 & 2 & 9.52 \\
\hline Total & 4,994 & 283 & 5.66 \\
\hline
\end{tabular}

${ }^{1}$ Progenies were raised using open-pollinated seed collected from individual Bourbon trees.

2 The joint estimate of the proportion of hybrids from the total of all the progenies is 0.0566 , with a standard error of 0.0033 .

TaBLE 2.-Spontaneous hybrids of Bourbon with Puerto Rican and Columnaris coffees in progenies from seed picked during $\&$ consecutive years, 1959-60, at the Agricultural Experiment Substation, Castañer P.R.

\begin{tabular}{|c|c|c|c|c|c|c|}
\hline \multirow{3}{*}{ Progeny' No. } & \multicolumn{6}{|c|}{ Data for years indicated } \\
\hline & \multicolumn{3}{|c|}{1959} & \multicolumn{3}{|c|}{1960} \\
\hline & Seedlings & Hybrids & $\begin{array}{l}\text { Proportion } \\
\text { of hybrids }\end{array}$ & Scedlings & Hybrids & $\begin{array}{l}\text { Proportion } \\
\text { of hybrids }\end{array}$ \\
\hline $\begin{array}{l}1 \\
2 \\
3 \\
4\end{array}$ & $\begin{array}{c}\text { Number } \\
371 \\
455 \\
336 \\
411\end{array}$ & $\begin{array}{c}\text { Number } \\
14 \\
34 \\
5 \\
8\end{array}$ & $\begin{array}{c}\text { Percent } \\
3.77 \\
7.47 \\
1.48 \\
1.94\end{array}$ & $\begin{array}{r}\text { Number } \\
53 \\
331 \\
306 \\
313\end{array}$ & $\begin{array}{c}\text { Number } \\
1 \\
54 \\
10 \\
9\end{array}$ & $\begin{array}{r}\text { Percent } \\
1.88 \\
16.31 \\
3.26 \\
2.87\end{array}$ \\
\hline Total & 1,573 & 61 & 3.88 & 1,003 & 74 & 7.38 \\
\hline
\end{tabular}

1 Progenies were raised using open-pollinated seed collected from individual Bourbon trees. 
TABLE 3.-Stalistical trealment of data in table 2-angles corresponding to percentages, angle $=$ arcsin/percentage as given by Snedecor (b)

\begin{tabular}{|c|c|c|c|c|c|c|}
\hline \multirow{2}{*}{\multicolumn{2}{|c|}{ Progeny No. }} & \multicolumn{3}{|c|}{ Data for- } & \multirow{2}{*}{\multicolumn{2}{|c|}{ Progeny totals }} \\
\hline & & 1959 & & 1960 & & \\
\hline \multicolumn{7}{|c|}{ Data } \\
\hline $\begin{array}{l}1 \\
2 \\
3 \\
4\end{array}$ & & $\begin{array}{r}11.2 \\
15.9 \\
7.0 \\
7.9\end{array}$ & & $\begin{array}{r}7.9 \\
23.8 \\
10.5 \\
9.8\end{array}$ & & \\
\hline \multicolumn{2}{|c|}{ Year totals } & 42.0 & & 52.0 & \multicolumn{2}{|c|}{94.0} \\
\hline \multicolumn{7}{|c|}{ Analysis of variance } \\
\hline $\begin{array}{l}\text { Source of } \\
\text { variation }\end{array}$ & D.F. & S.s. & M.S. & $\begin{array}{c}F \text { ratio } \\
\text { observed }\end{array}$ & $P \stackrel{P \text { for }}{=0.05}$ & $P \stackrel{F \text { for }}{=0.01}$ \\
\hline $\begin{array}{l}\text { Years } \\
\text { Progenies } \\
\text { Error }\end{array}$ & $\begin{array}{l}1 \\
\mathbf{3} \\
\mathbf{3}\end{array}$ & $\begin{array}{r}12.50 \\
175.72 \\
32.08\end{array}$ & $\begin{array}{l}12.50 \\
58.57 \\
10.69\end{array}$ & $\begin{array}{l}1.17 \\
5.48\end{array}$ & $\begin{array}{r}10.13 \\
9.28\end{array}$ & $\begin{array}{l}34.12 \\
29.46\end{array}$ \\
\hline
\end{tabular}

Tablez 4.-Spontaneous hybrids of Bourbon wilh Puerto Rican and Columnaris coffes in progenies from seed picked at 2 differcnt times during 1960, at the Agricullural Experiment Substation, Castañer, P.R.

\begin{tabular}{c|c|c|c|c|c|c}
\hline & \multicolumn{6}{|c}{ Data for time seed were collected } \\
\cline { 2 - 7 } Progeny' No. & \multicolumn{3}{|c|}{ First picking date } & \multicolumn{3}{|c}{ Second picking data } \\
\cline { 2 - 8 } & Seedlings & Hybrids & $\begin{array}{c}\text { Proportion } \\
\text { of hybrids }\end{array}$ & Seedlings & Hybrids & $\begin{array}{c}\text { Proportion } \\
\text { of hybrids }\end{array}$ \\
\cline { 2 - 8 } 1 & Number & Number & Percent & Namber & Number & Percent \\
2 & 26 & 0 & - & 27 & 1 & 3.70 \\
3 & 156 & 24 & 15.38 & 175 & 30 & 17.14 \\
4 & 160 & 3 & 1.87 & 146 & 7 & 4.79 \\
Total & 173 & 6 & 3.46 & 140 & 3 & 2.14 \\
\hline & 515 & 33 & 6.41 & 488 & 41 & 8.40 \\
\hline
\end{tabular}

\footnotetext{
${ }^{1}$ Progenies were raised using open-pollinated seed collected from individual Bourbon trees.

out of a total of 454 plants, 7.04 percent were spontaneous hybrids. Taking both the populations into account, out of a total of 1,126 plants 7.54 percent were spontaneous hybrids. The spontaneous hybrids were frequently observed in private Bourbon plantings and nurseries in different parts of the Coffee Region.
} 
During 1956-57, 14 crosses were attempted using Bourbon as the female parent and Puerto Rican as the male parent. The flowers ready to open were emasculated, hand-pollinated, and covered with cheesecloth bags. All the seed resulting from the crosses were sown. As the seed were over 6 months old the germination was rather poor.

Out of the 520 seedlings produced, 267 were studied when over 18 months old. It was found that 42.32 percent of them were hybrids and the rest were similar to Bourbon. It is possible that some pollen was shed before emascula-

TABLE 5.-Statistical treatment of dala in table 4-angles corresponding to percentages, angle $=$ arcsin $/$ percentage as given by Snedecor ( $b)$

\begin{tabular}{|c|c|c|c|}
\hline \multirow{2}{*}{ Progeny No. } & \multicolumn{2}{|c|}{ Data for time seed were collected } & \multirow{2}{*}{ Progeny totals } \\
\hline & First picking date & Second picking date & \\
\hline
\end{tabular}

\begin{tabular}{cc|c|c|c}
\hline \multicolumn{5}{|c}{ Dala } \\
\hline 1 & 0 & 11.1 & 11.1 \\
2 & 23.1 & 24.4 & 47.5 \\
3 & 7.9 & 12.7 & 20.6 \\
4 & 10.8 & 8.3 & 19.1 \\
\hline & \multirow{2}{*}{ Total } & 41.8 & 56.5 & 98.3 \\
\hline
\end{tabular}

Analysis of variance

\begin{tabular}{l|c|c|c|c|c|c}
\hline \multicolumn{1}{c|}{ Source of variation } & D.F. & S.S. & M.S. & $\begin{array}{c}F \text { ratio } \\
\text { observed }\end{array}$ & $\begin{array}{c}F \text { for } \\
P=0.05\end{array}$ & $\begin{array}{c}F \text { for } \\
P=0.01\end{array}$ \\
\hline Times seed collected & 1 & 27.01 & 27.01 & 1.62 & 10.13 & 34.12 \\
Progenies & 3 & 376.46 & 125.49 & 7.52 & 9.28 & 29.46 \\
Error & 3 & 50.08 & 16.69 & - & - & - \\
\hline
\end{tabular}

tion and selfing occurred. It is also possible that cheesecloth was not capable of protecting the flowers from contamination (table 6). The spontaneous hybrids were observed to be morphologically quite similar to those synthesized through controlled pollinations.

The data and observations led to the general conclusion that Bourbon spontaneously hybridizes with Puerto Rican and Columnaris. The extent of spontaneous hybridization varied greatly with location and, also to a minor extent, with year and month the open-pollinated Bourbon seed were harvested for raising the plants. The variations appear to be caused by differences in the abundance of pollen of Puerto Rican and Columnaris, the velocity and direction of wind, the kind and size of insect populations, weather and other conditions at the time of blooming of Bourbon. 


\section{SPONTANEOUS HYBRIDIZATION OF CERA AND \\ OTHER ARABICA-TYPE COFFEES}

On examining the open-pollinated seed lots from eight trees of Cera, it was found that 7 to $\mathbf{1 1 . 3 2}$ percent of them resulted from spontaneous hybridization of Cera with pollen from other Arabic-type coffees. The joint estimate of the proportion of spontaneous hybrids from the total of 6,284 seed comprising all the 8 progenies was $\mathbf{0 . 0 8 5 5}$, with a standard error of 0.0035 (table 7). Similar results were reported also by Krug and Carvalho (2).

TABLE 6.-Resulls from hybridizing coffee varielies and species through controlled pollinations at the Agricultural Experiment Substalion, Castañer, P.R. 1956-57

\begin{tabular}{|c|c|c|c|c|c|c|c|c|c|c|}
\hline Female parent & Male parent & Crosses & Flowers & Fruits & Seed & $\begin{array}{l}\text { Seed- } \\
\text { lings }\end{array}$ & $\begin{array}{c}\text { Sced } \\
\text { germi- } \\
\text { nated }\end{array}$ & $\begin{array}{l}\text { Seed- } \\
\text { lings ex- } \\
\text { amined } \\
\text { for find- } \\
\text { ing hy- } \\
\text { brids }\end{array}$ & $\begin{array}{l}\text { Hybrids } \\
\text { identi- } \\
\text { fied }\end{array}$ & $\begin{array}{l}\text { Hybrids } \\
\text { in the } \\
\text { seedling } \\
\text { sample } \\
\text { exa- } \\
\text { mined }\end{array}$ \\
\hline & & Number & Number & Number & Number & Number & Percent & Number & Number & Percent \\
\hline Bourbon & $\begin{array}{l}\text { Puerto } \\
\text { Rican }\end{array}$ & 14 & 3,012 & 1,575 & 2,344 & 520 & 32.18 & 267 & 113 & 42.32 \\
\hline $\begin{array}{l}\text { Puerto Ri- } \\
\text { can }\end{array}$ & & 7 & 1,940 & 907 & 1,298 & 293 & 22.57 & 293 & 2 & .68 \\
\hline $\begin{array}{l}\text { Puerto Ri- } \\
\text { can }\end{array}$ & Robusta & 19 & 6,709 & 3,316 & 4,420 & 1,090 & 24.66 & 1,090 & 8 & .73 \\
\hline
\end{tabular}

1 The germination was poor as the seed lots were over 6 months old when sown.

\section{SPONTANEOUS HYBRIDIZATION OF OTHER \\ ARABICA-TYPE COFFEES}

Plants appearing to be spontaneous hybrids such as Puerto Rican $\mathbf{x}$ Columnaris and Caturra $x$ Puerto Rican, were observed in commercial as well as in experimental coffee plantings. They seemed to be quite similar morphologically to many of the corresponding hybrids synthesized through controlled pollinations.

\section{SPONTANEOUS HYBRIDIZATION OF EXCELSA AND PUERTO RICAN}

Two spontaneous hybrids of Excelsa and Puerto Rican coffees were identified in a nursery of about 10,000 plants raised from open-pollinated seed collected from Excelsa growing mixed with Puerto Rican.

Three spontaneous hybrids of these coffees were encountered on searching many commercial plantings where Puerto Rican and Excelsa grew mixed, and the farmers used coffee seedlings arising from open-pollinated seed for establishing new plantings. The spontaneous hybrids appeared to 
be intermediate morphologically between the parental types. Their progenies showed much segregation. Some of the individuals resembled the parental types and the $F_{1}$ hybrids whereas the others appeared to be new genetic recombinations (figs. 1,2).

Seven crosses were attempted during 1956-57, using Puerto Rican as the female and Excelsa as the male parent. The flowers ready to open were emasculated, hand-pollinated, and covered with cheesecloth bags. All the seed resulting from the crosses were sown. As the seed were over 6 months old the germination was rather poor.

Out of the 293 seedlings produced, only 2 were hybrids and the others

TABLE 7.-Spontaneons hybrids of Cera with other Arabica-type coffees in seed collected during 1961, at the Agricultural Experiment Substation,

Castañer, P.R.

\begin{tabular}{|c|c|c|c|}
\hline Progeny' No. & Sced & Hybrid seed & Proportion of hybrid sced \\
\hline & Number & Number & Percent \\
\hline 1 & 1,280 & 94 & 7.34 \\
\hline 2 & 414 & 34 & 8.21 \\
\hline 3 & 638 & 45 & 7.05 \\
\hline 4 & 390 & 39 & 10.00 \\
\hline 5 & 936 & 106 & 11.32 \\
\hline 6 & 1,243 & 120 & 9.65 \\
\hline 7 & 871 & 61 & 7.00 \\
\hline 8 & 512 & 38 & 7.42 \\
\hline Total & 6,284 & 537 & 8.55 \\
\hline
\end{tabular}

1 Progenies comprised open-pollinated seed collected from individual Cera trees.

2 'The joint estimate of the proportion of hybrids from the total of all the progenies is 0.0855 , with a standard of error 0.0035 .

were similar to Puerto Rican. It is possible that some pollen was shed before emasculation and selfing occurred. It is also possible that using cheesecloth was insufficient to protect flowers from contamination (table 6). The spontaneous hybrids and those synthesized through controlled pollinations were observed to be quite similar morphologically (fig. 1).

Despite large-scale hand-pollinations only two hybrids of Puerto Rican and Excelsa could be synthesized. Conditions are favorable for the occurrence of spontaneous hybridization in many plantations: Excelsa is selfsterile, it is predominantly cross-pollinated, and its time of flowering overlaps that of Puerto Rican grown mixed with it. However, on observing large populations of Excelsa and Puerto Rican arising from open-pollinated seed collected from mixed plantings, only five spontaneous hybrids of these coffees could be found. The very low frequency of hybrids recovered indi- 
cates that the rate of spontaneous hybridization of Excelsa and Puerto Rican is extremely low, and this may result from the existence of strong isolation barriers between these coffee species.

\section{SPONTANEOUS HYBRIDIZATION OF ROBUSTA AND PUERTO RICAN}

In a nursery of about 10,000 plants raised from open-pollinated seed of Robusta growing mixed with Puerto Rican, several plants appeared to be spontaneous hybrids of these coffees.
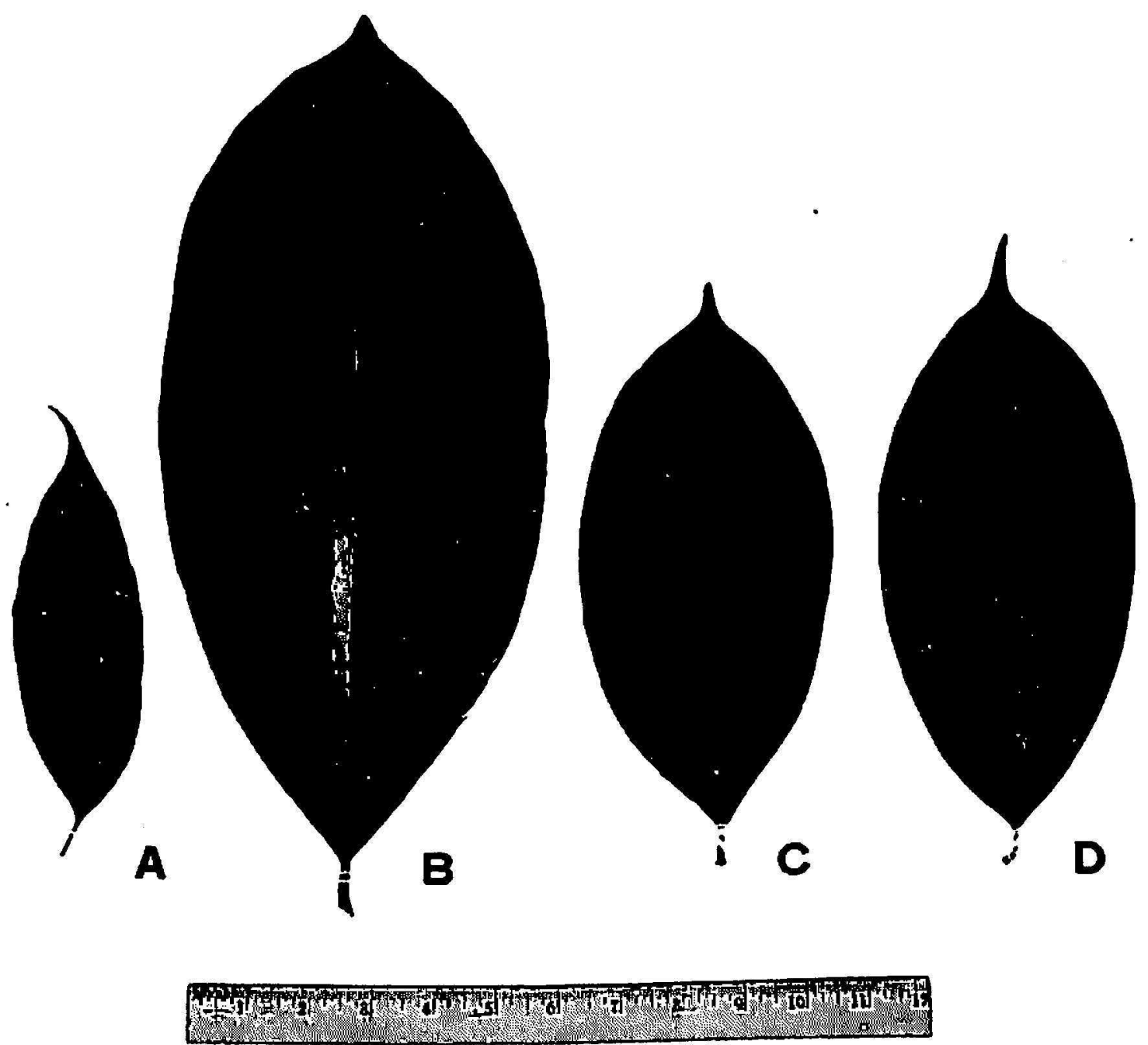

Fia. 1.-Fully developed coffee leaves: A, Puerto Rican; 13, Excelsa; C, spontaneous hybrid of Excelsit and J'uerto Rican; 1), synthesized hybrid of Puerto Rican and Excelsa.

On searching many commercial plantings where Puerto Rican and Robusta were mixed, and the farmers used coffee seedlings arising from openpollinated seed for establishing new plantings, only two spontaneous hybrids of these coffees were encountered. 
Nineteen crosses were attempted during $1956-57$, using Puerto Rican as the female and Robusta as the male parent. The flowers ready to open were emasculated, hand-pollinated, and covered with cheesecloth bags. All the seed resulting from the crosses were sown. As the seed were over 6 months old, the germination was rather poor.
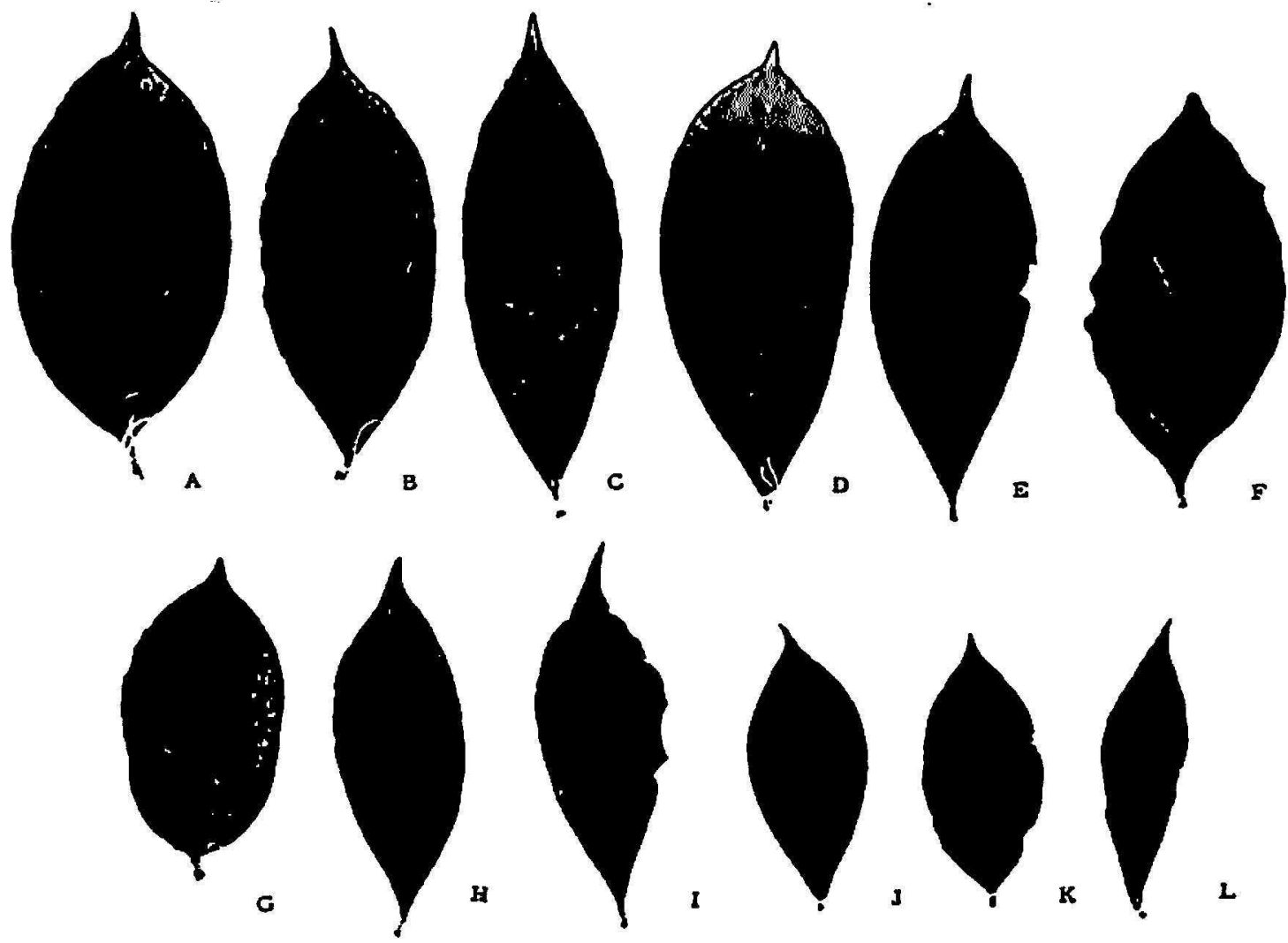

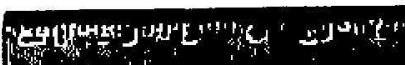

Fig. 2.-Fully developed colfee leaves each from individual seedlings, $A$ to $\mathrm{L}$, of $F_{2}$ progeny of a spontaneous lyblitid of Execlsa and P'uerto Rican.

Of the 1,090 seedlings produced, only 8 were hybrids. The rest of the seedlings were similar to Puerto Rican. It is possible that some pollen was shed before emasculation and selfing occurred. It is also possible that cheesecloth was not sufficient to protect the flowers from contamination (table (i).

The spontaneous hybrids and those synthesized through controlled pollinations were observed to be (fuite similar morphologically (fig. 3). Only eight hybrids of Puerto Rican and Robusta could be synthesized by carrying on large-scale hand-pollinations. In many plantations conditions are favorable for the occurrence of spontaneous hybridization: Robusta is 
self-sterile, is predominantly cross-pollinated, and its time of flowering overlaps that of Puerto Rican grown mixed with it. However, on observing large populations of Robusta and I'uerto Rican arising from open-pollinated seed collected from mixed plantings, a very small number of spontancous hybrids of these coffees could be found. The very low frequency of hybrids
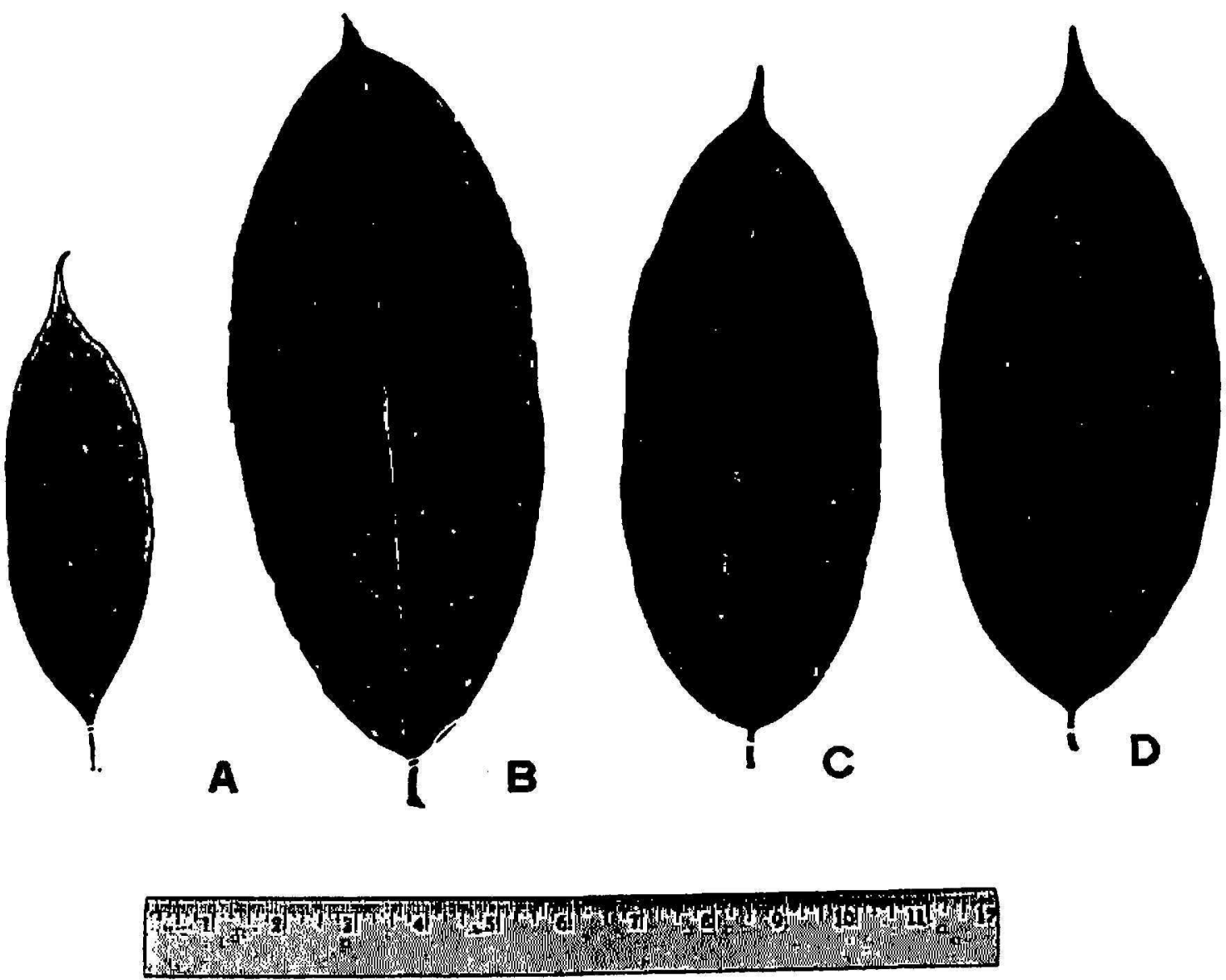

Fis. 3.-Fully developed coffec leaves: A, Puerto Ricin; B, Robusta; C, spontaneous hybrid of P'uerto Rican and Robusta; 1), synthesized hybrid of P'uerto Ricin and Robusta.

recovered indicates that the rate of spontaneous hybridization of Robusta and Puerto Rican is extremely low, and this may occur because of the existence of strong isolation barriers between these coffees species.

\section{CONCLUSIONS}

The present study shows that varieties and species of (Cof/ea grown in Puerto Rico spontancously hybridize when planted mixed or close to one another.

Occasionally spontancous coffee hybrids may prove useful for developing new varieties of economic importance $(1,3)$. However, as such, they are generally inferior to one or both the parental types. 
Most of the farmers have long been planting different varieties and species of Coffca mixed, and using open-pollinated seed from them for establishing new plantings. Thus conditions have been favorable for the occurrence of spontaneous hybridization and, thereby, increasing genetic variability. Consequently, careful selection may help in improving the different coffees.

Selection of individual coffee trees, testing of their progenies, obtaining foundation seed through controlled pollinations, and their multiplication in isolated plots are some of the necessary steps which should be followed to produce selected seed for commercial production. If a farmer produces the coffee seed himself, and is unable to take all these steps, he can at least go to the center of a ficld planted only with the desired coffee variety, select a small number of trees by observing their yields and other characters for one or more crops, use their seed for raising the planting material, and discard all the off-type plants.

The present study indicated that different varietics and species of Coffca occurring together in their natural habitats may have been hybridizing and thus contributing to the evolution of the genus. Thus increased variability from natural hybridization might be one of the reasons for confusion in the taxonomic treatment of the genus.

\section{SUMMARY}

P'uerto Rican, Columnaris, and Bourbon varieties of Coffea arabica are commonly grown in Puerto Rico. In some localities there are small plantings also of other coffees, such as Excelsa (C. excelsa) and Robusta (C. canephora). Recently some farmers have started testing several newly introduced Arabica-types coffees, such as Caturra, Villalobos, Mundo Novo, Mibirizi, and so on.

The farmers generally establish mixed plantings of different coffee varieties and species rather than planting them in separate plots. The time of flowering of these coffees overlaps. These conditions are favorable to spontaneous hybridization.

Spontaneous hybridization of Bourbon with Puerto Rican and Columnaris was studied, using the genetic tester "bronze." In one of the experiments 18 progenies were raised using open-pollinated seed collected from individual Bourbon trees growing mixed with Puerto Rican and Columnaris at different locations. In these progenies the proportion of spontaneous hylorids varied from 0 to 34.14 percent. Taking all the progenies into account, out of a total of 4,994 plants studied, 5.66 percent were spontaneous hybrids. In another experiment two populations were raised using openpollinated random seed samples collected from a Bourbon planting surrounded by Puerto Rican and Columnaris plantings. Out of a total of 
1,126 plants of both populations, 7.54 percent were spontaneous hybrids. Taking both experiments into account, out of a grand total of 6,120 plants studied, 6.01 percent were spontaneous hybrids.

The extent of spontaneous hybridization of Bourbon with Puerto Rican and Columnaris varied with years and months of the same year during which the open-pollinated Bourbon seed were collected for raising the plants. However, the differences were not statistically significant.

The spontaneous hybrids of Bourbon with Puerto Rican and Columnaris were observed to be similar morphologically to those synthesized through controlled pollinations.

The spontaneous hybridization of Cera with other Arabica-type coffees was studied, using the genetic tester "Cera." On examining the open-pollinated seed lots from eight Cera trees growing in a plot surrounded by many other Arabica-type coffees, it was found that 7 to 11.32 percent of them were produced through spontaneous hybridization of Cera with pollen from other Arabica-type coffees. Taking all the seed lots into account, out of a total of 6,284 seed examined, 8.55 percent were of hybrid origin.

On searching many coffee plantations and studying large populations raised from open-pollinated seed, only a very small number of spontaneous hybrids of Puerto Rican with Excelsa and Robusta could be found. Likewise, in spite of carrying on large-scale hand-pollinations, only a very small number of hybrids of these coffees could be produced. It was observed that the spontaneous and the synthesized hybrids of these coffees were morphologically quite similar.

The present study shows that varieties and species of Coffea grown in Puerto Rico spontaneously hybridize when planted mixed, or close to one another and, thereby, increase genetic variability. Consequently, careful selection may help to improve the different coffees varieties and species. When genetically superior individual coffee trees are selected, foundation seed should be produced through controlled pollinations and multiplied in isolated plots.

\section{RESUMEN}

Las variedades de Coffea arabica que se cultivan comúnmente en Puerto Rico son Puerto Rico, Columnaris y Borbón. En algunas localidades también hay pequeñas siembras de otras especies de café, tales como Excelsa (C. excelsa) y Robusta (C. canephora). Recientemente, algunos agrícultores han comenzado a probar otras variedades de café tipo arábigo, tales como Caturra, Villalobos, Mundo Novo, Mibirizi, etc., introducidas del extranjero.

Estudiamos la hibridación espontánea de Borbón con Puerto Rico y Columnaris usándose el carácter genético "bronze" como criterio. En un 
experimento se sembraron 18 progenies usándose semilla de árboles de Borbón, polinizada al natural, en piezas mixtas de distintas localidades que contenían también árboles de las variedades Puerto Rico y Columnaris. En estas progenies la proporción de híbridos espontáneos varió de 0 a 34.14 por ciento. Si se cuentan todas las progenies, hubo 5.66 por ciento de híbridos espontáneos en un total de 4,994 plantas estudiadas. En otro experimento se hicieron dos siembras experimentales usándose semilla polinizada al natural que se tomó al azar de una pieza de Borbón rodeada de plantaciones de las variedades Puerto Rico y Columnaris. De un total de 6,120 plantas estudiadas, 6.01 por ciento fueron híbridos espontáneo.

El grado de hibridación espontánea de la variedad Borbón con Puerto Rico y Columnaris varió de un año a otro y de un mes a otro en el mismo año durante la época en que se recolectó la semilla polinizada al natural para propagarse. No obstante, desde el punto de vista estadístico las diferencias fueron insignificantes.

Se notó que los híbridos espontáneos de Borbón con Puerto Rico y Columnaris eran morfológicamente iguales a los producidos por hibridación controlada.

Se estudió la hibridación espontánea de la variedad Cera con otras variedades de café tipo arábigo, usándose el carácter genético "cera" como criterio. Al examinarse los lotes de semilla polinizada al natural de 8 de los árboles de café Cera que crecían en una siembra rodeada de otras variedades de tipo arábigo, se encontró que el porcentaje de semilla por hibridación espontánea de la variedad Cera con el polen de otras del tipo arábigo varió entre 7.00 y 11.32 . Si se cuenta toda la semilla, de un total de 6,284 semillas examinadas el 8.55 por ciento era de origen híbrido.

La inspección de muchas plantaciones de café y el estudio de muchos árboles de semilla polinizada al natural reveló que el número de híbridos espontáneos de la variedad Puerto Rico con Excelsa y Robusta era muy pequeño. De igual manera, y pese al número considerable de polinizaciones controladas, se lograron muy pocos de estos híbridos. Se observó que los híbridos espontáneos y los controlados eran morfológicamente muy parecidos.

Este estudio demuestra que las variedades y especies de Coffea que se cultivan en Puerto Rico se cruzan espontáneamente y producen híbridos al sembrarse juntas o próximas unas a las otras, aumentando así la variabilidad genética. Por lo tanto, la selección cuidadosa de árboles para semilla puede contribuir grandemente al mejoramiento de las distintas variedades. Una vez seleccionados los árboles genéticamente superiores, la semilla que va a usarse debe producirse mediante la polinización controlada y luego multiplicarse en predios aislados. 


\section{LITERATURE CITED}

1. Cramer, P.J.S., Review of Literature of Coffee Research in Indonesia, InterAmerican Inst. of Agr. Sci. Turrialba, Costa Rica, Mis. Pub. 15, pp. 59-61 and 143-44, 1957.

2. Krug, C. A., and Carvalho, A., The Genetics of Coffea, Advances in Genetics, Academic Press Inc., New York, N.Y., 4, pp. 127-58, 1951.

3. - Coffee Breeding, Report of the 13th International Hort. Cong., pp. 1-11, 1952.

4. Singh-Dhaliwal, T., Desarrollo de estirpes o biotipos superiores de café mediante la selección, la hibridación y la propagación asexual para su cultivo en Puerto Rico, Rev. de Agr. de P.R. 44 (2) 59-77, 1957.

5. Snedecor, George W., Two-way experiments analysis of variance, Statistical Methods Applied to Experiments in Agriculture and Biology, Iowa State College Press, Ames, Iowa, pp. 316-9, 1957.

6. Sybenga, Jacob, Genética y citología del café, Una revisión de literatura, Turrialba, Inter-American Inst. of Agr. Sci. Turrialba, Costa Rica, 10 (3) 88-9, 1960. 